\title{
Evaluation of Year 6 KSSR English (SK) Textbook: Teachers' Perspectives
}

\author{
Nithya Kalyany Ponnusamy \& Iswaran Gunasegaran \\ School of Education, Faculty of Social Sciences and Humanities, Universiti Teknologi Malaysia, \\ 81310 UTM Johor Bahru, Johor, Malaysia \\ Shanti C Sandaran* \& Nur-al Huda Hashim \\ Language Academy, Faculty of Social Sciences and Humanities, Universiti Teknologi Malaysia, \\ 81310 UTM Johor Bahru, Johor, Malaysia
}

Submitted: 12/8/2019. Revised edition: 24/6/2021 Accepted: 25/06/2021. Published online: 28/6/2021

\begin{abstract}
Textbook evaluation is the process for ensuring that the right textbook is selected for use in the teaching and learning scenario. During educational reforms, such as the adoption of the Common European Framework of Reference for the ELT scenario, textbook evaluation should be a crucial part of the textbook selection process. In Malaysia, with the adoption of CEFR, new books such as the Super Minds and Get Smart, which are imported textbooks, have replaced locally produced books. The Year 6 KSSR (SK) English textbook is currently still in use but would be phased out in the near future as part of the CEFR reform. Since the introduction of the 'global' textbooks, there have been mixed concerns amongst teachers and researchers about the suitability of the imported textbooks. This study investigated the effectiveness and suitability of the currently-in-use KSSR Year 6 English (SK) textbook, which was locally produced. It looked at the perceptions of teachers on the general attributes of the textbook, such as syllabus and curriculum, the methodology, the book's suitability to learners, as well as the learningteaching content such as skills, grammar, vocabulary, exercises, and pronunciation, etc. Adopting a mixed method design, Nimehchisalem \& Mukundan's (2015) revised textbook evaluation checklist was used as the instrument for the quantitiative part, where twenty, Year 6 English teachers, from three primary schools in the Kulai district (in Johor) evaluated the textbook. For the qualitative part, five teachers were involved in semi-structured interviews. The findings showed that the teachers perceived the Year 6 KSSR English SK Textbook that is currently used in primary (SK) schools, as highly useful for the learners, in terms of both the general attributes as well as learning-teaching content. Our findings highlight that locally produced textbooks are better suited for our learners, and if imported 'global' textbooks replace the local ones, they should first be customized (custom textbooks) that would be infused with local cultures, etc, to be better suited to local learner needs.
\end{abstract}

Keywords: Textbook Evaluation, CEFR, Year 6 KSSR English Textbook, Custom Textbook

\subsection{INTRODUCTION}

Textbook as the printed form of instructional material in educational settings, plays a vital role in the teaching and learning process. It provides teachers with a great help in course and activity design and

\footnotetext{
*Correspondence to: Shanti C Sandaran (email: shanti@utm.my)
} 
becomes the main reference for teachers in the classroom due to several reasons. First, the textbook is comparatively easy to find and commercially, as well as officially provided. Second, it gives a clearer view and a road map for learners to perform their expected behavior (Renandya, 2002). Third, the textbook guides teachers to prepare the lesson (Brown, 2000). Lastly, the textbook can be easily adapted depending on the sdents' level and needs. Thus, with so much importance being given to textbooks, teachers need to be more informed and involved in the process of selecting and utilising the textbook for maximum benefit for students. To this end, textbook evaluation has become a necessity for teachers and curriculum designers as a reference for refining or modifying textbooks.

According to Mukundan \& Kalajahi (2013) in the education ecosystem, a good choice of material is essential in producing competent language learners and thus, textbook is a main guide and source for teachers. Hence, textbook evaluation is a means to ensure that the components and elements of the textbook are effective and suitable from the cover, right up to the contents. As the number of textbooks keep on increasing in the market, selecting the right textbook is very crucial for the teaching and learning process (Cunningsworth, 1995). This means that a quality textbook is very crucial as it can determine the success or failure of a teaching and learning (Mukundan et al., 2011). Sadly, many textbooks are chosen without detailed analyses and usually being bought because of a prestige author or publisher (McGrath, 2002). Highest preference will be given to books printed in colours with catchy covers or top-selling textbooks used in many other locations (McGrath, 2002 and Tomlinson, 2008). Textbooks for ELT are also selected based on educational reforms. One such change that has taken place globally, is the implementation of the Common European Framework of Reference for Languages (CEFR).

The CEFR was formulated in 2001 and designed to establish international standards for foreign language education to cater to the needs of language learners as well as academics and other professions related to assessment, teaching and learning of languages. CEFR describes quite thoroughly what language learners are required to accomplish to communicate using a language. Language users are clustered into three main groups: Proficient users (levels C1 \& C2), Independent users (levels B1 \& B2) and Basic users (levels A1 \& A2). Detailed descriptors of what learners are able to do are known as the "can do" statements for listening, writing, readings and speaking skills.

(Mohamad Uri \& Mohd Abd Aziz, 2018, p.168)

In Malaysia, the introduction of the CEFR was a move to not only improve the proficiency of students, but it was also to elevate the proficiency of the English Language teachers. While the CEFR implementation saw various measures such as the upskilling of the English Language teachers, this has also led to the adoption of internationally produced CEFR aligned textbooks to replace the current-in-use locally produced textbooks. The adoption of the CEFR aligned textbooks has taken place in stages. Books such as Super Minds, Get Smart Plus 3 have been introduced for Years 1, 2 and 3. Many, especially teachers, have since criticised the use of the globally produced textbooks as being not suitable for local use especially in terms of for example, cultural content, as the new textbooks are based on international cultural elements (Mohamad Lukman Al Hadi \& Parilah Mohd Shah, 2020). Various studies have since been conducted on the suitability of the globally produced textbooks and the mixed perceptions of teachers as well as some limitations of the textbooks (e.g., Mohamad Uri \& Mohd Abd Aziz (2018); Mohammad Din \& Yamat, (2020); Johar \& Abdul Aziz, (2019). These studies 
also highlighted the importance of teachers' perceptions about the effectiveness of the textbooks that are in use.

In following such views, the current study was conducted to investigate the effectiveness and suitability of the currently-in-use KSSR Year 6 English SK textbook from the point of view of teachers, in terms of the general attributes of the textbook in relation to syllabus and curriculum, the methodology, the book's suitability to learners, physical and utilitarian attributes, and efficient outlay of supplementary materials and learning-teaching content focusing on four the main major skills which are grammar, vocabulary, exercises, and pronunciation. The KSSR Year 6 English textbook is one of the textbooks that would be phased out soon and replaced with the internationally produced CEFR aligned textbooks such as Get Smart. Despite the textbook being phased out, it is still important to find out how Malaysian teachers perceived of the textbook to understand the effectiveness, strengths, and weaknesses of the textbook. The findings would be valuable to textbook developers, administrators, and policy makers, and especially teachers themselves, who could take up the task as textbook developers.

\subsection{TEXTBOOK AS AN INSTRUCTIONAL MATERIAL FOR TEACHING \& LEARNING}

In the teaching and learning process, instructional materials are vital to the sustenance of language instructions. Richards (2001) concluded that many language programmes in the world could not happen without the presence of commercial materials. Adding on, Tomlinson (1998) claims that materials are mainly meant to help learners develop their knowledge and give them chances to practice language use. Sheldon (1988) has defined 'textbook' as a specially made learning aid for language learners in improving their aural, oral, and linguistic competence. Neill (1982) describes a textbook as map and tangible outlines $w \mathrm{~h}$ i $\mathrm{ch}$ a $\mathrm{re}$ organised in a flexible way to assist the language learning to happen. The teaching learning process is like a ride which $\mathrm{u}$ s e s textbooks as a guideline to achieve its goals and the guideline delivers some ideas that should be accomplished during this knowledgeable ride. Apart from being a language learning tool, the textbook is also used in assisting teachers in the teaching and learning process (Neill, 1982 and Ur, 1996). Tomlinson (1998) and Masuhara (2010) concluded that the learner's book was attached with some supporting materials like an activity book while teachers were supplied with a textbook and a teacher's guide as a supplementary material for them as well. The textbook has played an essential role in English Language Teaching (ELT) \& English as a Second Language (ESL) classrooms all over the countries (Williams, 1983). The essential need for textbooks in ELT \& ESL classrooms is so vital that they have become a widespread element in ELT teaching (Torres, 1995) and are essential to any ELT program (Sheldon, 1988).

Although textbooks play an important part in language classrooms, Richards (2001) states that debates have been circulating on the actual role of textbooks in EFL and ESL settings in relation to their limitations. Torres (1995) claims that as a world-wide component in all ELT classrooms, any teaching and learning situation will not be complete without a textbook. Similarly, Ur (1996) stresses on the explicit framework that textbook provides, which guides teachers and learners in 
their learning progress. She also reports that textbooks are a much more reasonable tool compared to other tools such as learning kits or computer software. Byrd (2001) proposes a good textbook only needs to fit into at least three components. These comprise proper curriculum and texts, students and texts, and teachers and texts. To fulfil the first aspect, textbook designers need to consider aspects of curriculum in a broader and smaller educational context. Next, to suit between teachers and texts, the textbook should cater the aspect of expressive content, understandable example, various and achievable activities, and interesting outlay of a textbook. Lastly, to fit between students and texts, textbook should have attractive contents, suitable example based on students' levels, various activities, and presentation.

Many studies have been conducted on ELT materials and textbook evaluation in different levels from primary, secondary and university levels. Each study has been conducted with different purposes and instruments. In some countries English Language teaching is based entirely on the prescribed language course books and even experienced teachers must rely on the textbooks due to several reasons. The ELT course books serve as the content for language teaching and are strictly followed in developing the tests for the examinations. A study by Krrköz (2009), found that the three evaluated English textbooks currently used by grade 4 classes in Turkish primary schools were designed in relation to meet the Turkish Ministry of Education's (MNE) curriculum objectives to meet the young learners' desires and interests. Both teachers and students answered 37 items in a textbook evaluation list and responded positively towards the usage of the textbook in terms of language content, layout and design, methodology and skills available in the textbook. The students also agreed that the textbook was beautifully illustrated and colourful and suited their level of proficiency. Yuasa (2010) evaluated English textbooks which were currently being used in Korea and Japan in relation to focus on the materials in the textbooks. The findings show that both countries enforced the learners to be interested in the English language by using interesting topics, issues, and eye-catching pictures and images. The only difference is the in the Japanese context, the English language is introduced to indulge the learners in a foreign culture and society while motivating them to use and communicate in the language. In the Koreans context, the objective for learning English is to express themselves and exchange views and ideas.

Ministry prescribed textbooks are a very important feature of the Malaysian ELT scenario. In recent years, with reforms in the ELT scenario, many changes have taken place in relation to textbooks. The most recent in the adoption of the Common European Framework of reference in ELT and the introduction of imported textbooks. This reform has led to more researchers focusing on the evaluation of currently used textbooks as well as the newer imported ones. For example, Takal et. al., (2021) looked at the newly introduced Get Smart Year Three textbook. The findings based on teachers' perceptions stated that the textbook is very useful but needs improvements as it lacks creativity in illustrations, sentence and paragraph structures in the writing part and challenging vocabulary use, has difficult words in the grammar explanations, and importantly it caters to a different culture than that of the learners. Others have investigated both the new and the previously used textbooks. Abdul Rahim \& Jalalian Daghigh (2019) raised the issue of whether the new imported textbooks meet local learner needs in terms of the cultural content. Their study looked at both the locally developed textbook for Form 1 students and the imported one used, namely Pulse 2. Their findings showed that the locally produced textbook's intercultural content, and the cultural spectrum 
is more in line with the objectives of intercultural communications competence (ICC). They concluded that replacing local textbooks with imported textbooks may not be in the best interest of Malaysia's goals on ELT. These studies highlight the importance of textbook evaluation for a better understanding of the suitability of textbooks and more so, of textbooks prescribed by the Ministry of Education. We extend upon such studies and investigate the perceptions of teachers who have been using the KSSR Year 6 English textbook.

\subsection{METHOD}

This study utilised a mixed method design which involved gathering quantitative and qualitative data to obtain a better understanding of the teachers' perceptions. The instrument for the quantitative part of the study is the modified and updated textbook evaluation checklist by Nimehchisalem \& Mukundan (2015), where validity and reliability had been tested. The checklist is a 39-item instrument, that follows a five-point Likert style scale, in which $0=$ 'never true'; $1=$ 'rarely true'; $2=$ 'sometimes true'; $3=$ 'often true'; 4='always true'; NA = non applicable. The checklist is divided into two main themes, namely I. General Attributes and II. Learning-Teaching Content. The main themes are further divided into subthemes with corresponding number of items. Under General Attributes, five subthemes include: A. The book in relation to syllabus and curriculum (items 1, 2), B. Methodology (Items 3, 4), C. Suitability to learners (Items 5, 6), D. Physical and utilitarian attributes (Items 7, 8, 9), E. Efficient layout of supplementary materials (Items 10, 11, 12). The LearningTeaching Content is divided into nine subthemes, namely, F. General Content (Items 13,14,15,16,17); G. Listening (Items 18,19,20); H. Speaking (Items 21,22); I, Reading (Items 23,24,25); J. Writing (Items 26,27); K. Vocabulary (Items 28,29,30,31); L. Grammar (Items 32, 33); M. Pronunciation (Items 34,35); N. Exercises (Items 36,37,38,39).

Twenty, Year 6 English teachers, from three primary schools in the Kulai district (in Johor) were selected to evaluate the textbook based on a textbook evaluation checklist provided to them. To enhance the quantitative findings, five teachers were selected for the qualitative data via semi structured interviews. Teachers selected are between $25-41$ years of age, with a minimum of five years' experience of teaching year 6 pupils. All the teachers have at least a bachelor's degree in English Language education or have attended a one-year training at a local teachers' training college. The twenty teachers evaluated the KSSR Year 6 textbook based on the checklist provided to them. The data collected from the checklist was tabulated in the LibreOffice 5.0 Software according to the subthemes. The mean and standard deviation were then derived for every subtheme evaluated. Nimehchisalem \& Mukundan (2015, p. 768-9), have also provided an interpretation guide. The twenty teachers used the checklist to evaluate the textbook by assigning a value of 0 to 4 . The researchers then add up the scores to calculate the total score, then divide this by the total number of items (i.e., $39)$. Thus, a value of $<20 \%$ is regarded as 'negligible', $20 \%-40 \%$ as 'low', $40 \%-70 \%$ as 'moderate', $70 \%-90 \%$ as 'high' and $>90 \%$ as 'very high'. For the qualitative data, five teachers were interviewed. Eight questions about the sufficiency, suitability, learning-teaching content, and English language 
skills were asked. The responses from the participants were recorded, transcribed, and coded into relevant themes for interpretation.

\subsection{RESULTS AND DISCUSSION}

The findings of both the quantitative and qualitative data are discussed in this section. The study aimed to investigate the effectiveness and suitability of the currently-in-use KSSR Year 6 English SK textbook from the point of view of teachers, in terms of the general attributes and learningteaching content. In the following subsections, we start with the findings from the textbook evaluation checklist followed by semi structured interviews.

\subsection{Teachers Perceptions about the Suitability of the KSSR Year 6 Textbook (Quantitative Data)}

Table 4.1 indicates the distribution of frequency and percentage of respondents' scores for the evaluated textbook based on the 39-item checklist. It shows that most of the respondents chose a score of 3 or 4 for the items. This clearly indicates that the evaluated textbook comprises all the items that should be in a good textbook. The teachers' evaluation showed that the new textbook covered all the important aspects of a good textbook as mentioned by Byrd (2001).

Table 4.1 Frequency and Percentage Distribution, Mean \& SD of Checklist Items

$$
\begin{aligned}
& 0=\text { Never true } \\
& 1=\text { Rarely true } \\
& 2=\text { Sometimes true }
\end{aligned}
$$

\begin{tabular}{|c|c|c|c|c|c|c|c|c|}
\hline Checklist Items & $\begin{array}{c}\text { Never } \\
\text { True } \\
(0) \\
\%\end{array}$ & $\begin{array}{c}\text { Rarely } \\
\text { True } \\
(1) \\
\%\end{array}$ & $\begin{array}{c}\text { Sometime } \\
\text { True } \\
(2) \\
\%\end{array}$ & $\begin{array}{c}\text { Often } \\
\text { True } \\
(3) \\
\%\end{array}$ & $\begin{array}{c}\text { Always } \\
\text { True } \\
(4) \\
\%\end{array}$ & $\begin{array}{c}\text { Not } \\
\text { Applicable } \\
\%\end{array}$ & Mean & SD \\
\hline \multicolumn{9}{|c|}{ I. General attributes } \\
\hline \multicolumn{9}{|l|}{$\begin{array}{l}\text { A. The book in relation to syllabus and } \\
\text { Curriculum }\end{array}$} \\
\hline $\begin{array}{l}\text { 1. It matches the specifications of the } \\
\text { syllabus. }\end{array}$ & Nil & Nil & $\mathrm{Nil}$ & $\begin{array}{l}f=16 \\
80 \%\end{array}$ & $\begin{array}{l}f=4 \\
20 \%\end{array}$ & Nil & 3.2 & 0.41 \\
\hline 2. Overall, the book has a nice feel. & Nil & Nil & $\begin{array}{l}f=4 \\
20 \%\end{array}$ & $\begin{array}{l}f=9 \\
45 \%\end{array}$ & $\begin{array}{l}f=7 \\
35 \%\end{array}$ & Nil & 3.2 & 0.77 \\
\hline \multicolumn{9}{|l|}{ B. Methodology } \\
\hline 3. The activities can be exploited fully. & Nil & Nil & $\mathrm{Nil}$ & $\begin{array}{l}f=15 \\
65 \%\end{array}$ & $\begin{array}{l}f=5 \\
35 \%\end{array}$ & Nil & 3.5 & 0.51 \\
\hline $\begin{array}{l}\text { 4. The activities can work well in most } \\
\text { classroom situations. }\end{array}$ & Nil & Nil & $\begin{array}{l}f=8 \\
40 \%\end{array}$ & $\begin{array}{l}f=6 \\
30 \%\end{array}$ & $\begin{array}{l}f=6 \\
30 \%\end{array}$ & Nil & 2.9 & 0.9 \\
\hline C. Suitability to learners & & & & & & & & \\
\hline
\end{tabular}

$$
\begin{aligned}
& 3 \text { = Often true } \\
& 4=\text { Always true } \\
& \text { NA = Not applicable }
\end{aligned}
$$




\begin{tabular}{|c|c|c|c|c|c|c|c|c|}
\hline $\begin{array}{l}\text { 5. It is compatible with the background } \\
\text { knowledge and level of students. }\end{array}$ & Nil & Nil & $\begin{array}{l}f=3 \\
15 \%\end{array}$ & $\begin{array}{l}f=11 \\
55 \%\end{array}$ & $\begin{array}{c}f=6 \\
30\end{array}$ & Nil & 3.2 & 0.67 \\
\hline 6. It addresses learning targets. & Nil & Nil & $\begin{array}{l}f=4 \\
20 \%\end{array}$ & $\begin{array}{l}f=11 \\
55 \%\end{array}$ & $\begin{array}{l}f=5 \\
25 \%\end{array}$ & Nil & 2.95 & 0.69 \\
\hline \multicolumn{9}{|l|}{ D. Physical and utilitarian attributes } \\
\hline 7. It is appropriately priced. & Nil & Nil & $\begin{array}{l}F=2 \\
10 \%\end{array}$ & $\begin{array}{l}f=12 \\
60 \%\end{array}$ & $\begin{array}{l}f=6 \\
30 \%\end{array}$ & Nil & 3.2 & 0.62 \\
\hline 8. Its layout is attractive. & Nil & Nil & $\begin{array}{l}f=1 \\
5 \%\end{array}$ & $\begin{array}{l}f=13 \\
65 \%\end{array}$ & $\begin{array}{l}f=6 \\
30 \%\end{array}$ & Nil & 3.25 & 0.55 \\
\hline $\begin{array}{l}\text { 9. It indicates efficient use of text and } \\
\text { visuals }\end{array}$ & Nil & Nil & $\begin{array}{l}f=2 \\
10 \%\end{array}$ & $\begin{array}{l}f=10 \\
50 \%\end{array}$ & $\begin{array}{l}f=8 \\
40 \%\end{array}$ & Nil & 3.30 & 0.66 \\
\hline \multicolumn{9}{|l|}{$\begin{array}{l}\text { E. Efficient layout of supplementary } \\
\text { Materials }\end{array}$} \\
\hline $\begin{array}{l}10 \text { The book is supported by suitable } \\
\text { material like a workbook, audio, or } \\
\text { multimedia. }\end{array}$ & $\begin{array}{l}f=5 \\
25 \%\end{array}$ & $\begin{array}{l}f=1 \\
5 \%\end{array}$ & $\begin{array}{l}f=9 \\
45 \%\end{array}$ & $\begin{array}{l}f=4 \\
25 \%\end{array}$ & Nil & Nil & 1.65 & 1.09 \\
\hline $\begin{array}{l}\text { 11. The book is supported by other } \\
\text { materials like review and test units. }\end{array}$ & $\begin{array}{l}f=4 \\
20 \%\end{array}$ & $\begin{array}{l}f=4 \\
20 \%\end{array}$ & $\begin{array}{l}f=9 \\
45 \%\end{array}$ & $\begin{array}{l}f=3 \\
15 \%\end{array}$ & Nil & Nil & 2.0 & 0.86 \\
\hline $\begin{array}{l}\text { 12. There is a useful teacher's guide to aid } \\
\text { the Teacher }\end{array}$ & $\begin{array}{l}f=3 \\
15 \%\end{array}$ & $\begin{array}{l}f=4 \\
20 \%\end{array}$ & $\begin{array}{l}f=6 \\
30 \%\end{array}$ & $\begin{array}{l}f=7 \\
35 \%\end{array}$ & Nil & Nil & 1.85 & 1.09 \\
\hline \multicolumn{9}{|l|}{ F. General content } \\
\hline 13. Tasks move from simple to complex. & Nil & $\begin{array}{l}f=2 \\
10 \%\end{array}$ & Nil & $\begin{array}{l}f=16 \\
80 \%\end{array}$ & $\begin{array}{l}f=2 \\
10 \%\end{array}$ & Nil & 2.9 & 0,72 \\
\hline 14. Tasks are varied & Nil & $\begin{array}{l}f=2 \\
10 \%\end{array}$ & $\begin{array}{l}f=4 \\
20 \%\end{array}$ & $\begin{array}{l}f=11 \\
55 \%\end{array}$ & $\begin{array}{l}f=3 \\
15 \%\end{array}$ & Nil & 2.75 & 0.85 \\
\hline 15. Tasks support teaching objectives. & Nil & $\begin{array}{l}f=2 \\
10 \%\end{array}$ & $\begin{array}{l}f=4 \\
20 \%\end{array}$ & $\begin{array}{l}f=10 \\
50 \%\end{array}$ & $\begin{array}{l}f=4 \\
20 \%\end{array}$ & Nil & 2.65 & 0.81 \\
\hline $\begin{array}{l}\text { 16. The language in the textbook natura } \\
\text { and real. }\end{array}$ & Nil & $\begin{array}{l}f=2 \\
10 \%\end{array}$ & $\begin{array}{l}f=5 \\
25 \%\end{array}$ & $\begin{array}{l}f=11 \\
55 \%\end{array}$ & $\begin{array}{l}f=2 \\
10 \%\end{array}$ & Nil & 2.65 & 0.81 \\
\hline 17. The material is fairly recent. & Nil & Nil & $\begin{array}{l}f=3 \\
15 \%\end{array}$ & $\begin{array}{l}f=16 \\
80 \%\end{array}$ & $\begin{array}{l}f=1 \\
5 \%\end{array}$ & Nil & 2.9 & 0.4 \\
\hline \multicolumn{9}{|c|}{ II. Language-teaching content } \\
\hline \multicolumn{9}{|l|}{ G. Listening } \\
\hline $\begin{array}{l}\text { 18. The book has appropriate listening } \\
\text { tasks with well-defined goals. }\end{array}$ & Nil & Nil & $\begin{array}{l}f=7 \\
35 \%\end{array}$ & $\begin{array}{l}f=6 \\
30 \%\end{array}$ & $\begin{array}{l}f=7 \\
35 \%\end{array}$ & Nil & 2.9 & 0.4 \\
\hline $\begin{array}{l}\text { 19. Tasks are authentic or close to real } \\
\text { language situations. }\end{array}$ & Nil & $\begin{array}{l}f=1 \\
15 \%\end{array}$ & $\begin{array}{l}f=8 \\
40 \%\end{array}$ & $\begin{array}{l}f=6 \\
30 \%\end{array}$ & $\begin{array}{l}f=5 \\
25 \%\end{array}$ & Nil & 3.1 & 0.91 \\
\hline $\begin{array}{l}\text { 20. Various listening contexts such as } \\
\text { formal } \\
\text { vs. informal contexts are considered. }\end{array}$ & Nil & $\begin{array}{l}f=3 \\
15 \%\end{array}$ & $\begin{array}{l}f=2 \\
20 \%\end{array}$ & $\begin{array}{l}f=9 \\
45 \%\end{array}$ & $\begin{array}{l}f=6 \\
30 \%\end{array}$ & Nil & 2.75 & 0.91 \\
\hline \multicolumn{9}{|l|}{ H. Speaking } \\
\hline $\begin{array}{l}\text { 21. Activities are developed to initiate } \\
\text { meaningful communication. }\end{array}$ & Nil & $\begin{array}{l}f=2 \\
10 \%\end{array}$ & $\begin{array}{l}f=5 \\
25 \%\end{array}$ & $\begin{array}{l}f=10 \\
50 \%\end{array}$ & $\begin{array}{l}f=3 \\
15 \%\end{array}$ & Nil & 3 & 0.73 \\
\hline $\begin{array}{l}\text { 22. Individual, pair and group work are } \\
\text { given equal emphasis. }\end{array}$ & Nil & $\begin{array}{l}f=2 \\
10 \%\end{array}$ & Nil & $\begin{array}{l}f=12 \\
60 \%\end{array}$ & $\begin{array}{l}f=6 \\
30 \%\end{array}$ & Nil & 3.1 & 0.85 \\
\hline I. Reading & & & & & & & & \\
\hline
\end{tabular}




\begin{tabular}{|c|c|c|c|c|c|c|c|c|}
\hline 23. Length is appropriate. & Nil & Nil & $\begin{array}{l}f=4 \\
20 \%\end{array}$ & $\begin{array}{c}f=12 \\
60 \%\end{array}$ & $\begin{array}{l}f=4 \\
20 \%\end{array}$ & Nil & 2.9 & 0.64 \\
\hline 24. Difficulty level is appropriate. & $\mathrm{Nil}$ & & & $\begin{array}{c}f=16 \\
80 \%\end{array}$ & $\begin{array}{l}f=4 \\
20 \%\end{array}$ & Nil & 3.2 & 0.41 \\
\hline 25. Texts are interesting & Nil & $\begin{array}{l}f=2 \\
10 \%\end{array}$ & Nil & $\begin{array}{c}f=12 \\
60 \%\end{array}$ & $\begin{array}{l}f=6 \\
30 \%\end{array}$ & Nil & 3.2 & 0.62 \\
\hline \multicolumn{9}{|l|}{ J. Writing } \\
\hline $\begin{array}{l}\text { 26. Tasks have achievable goals and take } \\
\text { into } \\
\text { consideration learner capabilities. }\end{array}$ & Nil & $\begin{array}{l}f=2 \\
10 \%\end{array}$ & $\begin{array}{c}f=1 \\
5 \%\end{array}$ & $\begin{array}{c}f=14 \\
70 \%\end{array}$ & $\begin{array}{l}f=3 \\
15 \%\end{array}$ & Nil & 2.9 & 0.79 \\
\hline 27. Tasks are interesting. & Nil & $\begin{array}{l}f=2 \\
10 \%\end{array}$ & $\begin{array}{l}f=2 \\
10 \%\end{array}$ & $\begin{array}{c}f=12 \\
60 \%\end{array}$ & $\begin{array}{l}f=4 \\
20 \%\end{array}$ & Nil & 2.85 & 0.88 \\
\hline \multicolumn{9}{|l|}{ K. Vocabulary } \\
\hline $\begin{array}{l}\text { 28. The load (number of new words in each } \\
\text { lesson) is appropriate to the level of } \\
\text { students. }\end{array}$ & Nil & $\begin{array}{l}f=2 \\
10 \%\end{array}$ & Nil & $\begin{array}{c}f=15 \\
75 \%\end{array}$ & $\begin{array}{l}f=3 \\
15 \%\end{array}$ & Nil & 2.95 & 0.76 \\
\hline $\begin{array}{l}\text { 29. There is a good distribution (simple to } \\
\text { complex) of vocabulary load across } \\
\text { chapters and the whole book. }\end{array}$ & Nil & Nil & $\begin{array}{l}f=5 \\
25 \%\end{array}$ & $\begin{array}{c}f=10 \\
50 \%\end{array}$ & $\begin{array}{l}f=5 \\
25 \%\end{array}$ & Nil & 3.0 & 0.73 \\
\hline $\begin{array}{l}\text { 30. New words are sufficiently repeated and } \\
\text { recycled across the book. }\end{array}$ & $\mathrm{Nil}$ & $\begin{array}{l}f=2 \\
10 \%\end{array}$ & $\begin{array}{l}f=3 \\
15 \%\end{array}$ & $\begin{array}{l}f=2 \\
10 \%\end{array}$ & $\begin{array}{l}f=13 \\
65 \%\end{array}$ & Nil & 2.85 & 0.88 \\
\hline 31. Words are contextualized & Nil & Nil & $\begin{array}{l}f=5 \\
25 \%\end{array}$ & $\begin{array}{l}f=10 \\
50 \%\end{array}$ & $\begin{array}{l}f=5 \\
25 \%\end{array}$ & Nil & 3.0 & 0.73 \\
\hline \multicolumn{9}{|l|}{ L. Grammar } \\
\hline 32. Grammar is contextualized. & Nil & Nil & $\begin{array}{l}f=6 \\
30 \%\end{array}$ & $\begin{array}{l}f=11 \\
55 \%\end{array}$ & $\begin{array}{l}f=3 \\
15 \%\end{array}$ & Nil & 2.85 & 0.67 \\
\hline $\begin{array}{l}\text { 33. Grammar items are repeated } \\
\text { throughout the } \\
\text { book. }\end{array}$ & Nil & $\begin{array}{l}f=2 \\
10 \%\end{array}$ & $\begin{array}{l}f=4 \\
20 \%\end{array}$ & $\begin{array}{l}f=11 \\
55 \%\end{array}$ & $\begin{array}{l}f=3 \\
15 \%\end{array}$ & Nil & 2.9 & 0.89 \\
\hline \multicolumn{9}{|l|}{ M. Pronunciation } \\
\hline 34. Tasks are useful. & Nil & Nil & $\begin{array}{l}f=4 \\
20 \%\end{array}$ & $\begin{array}{l}f=14 \\
70 \%\end{array}$ & $\begin{array}{l}f=2 \\
10 \%\end{array}$ & Nil & 2.85 & 0.59 \\
\hline 35. Tasks are interesting. & Nil & $\begin{array}{l}f=4 \\
20 \%\end{array}$ & $\begin{array}{l}f=3 \\
15 \%\end{array}$ & $\begin{array}{l}f=11 \\
55 \%\end{array}$ & $\begin{array}{l}f=2 \\
10 \%\end{array}$ & Nil & 2.85 & 0.59 \\
\hline 36. They have clear instructions. & Nil & Nil & $\begin{array}{l}f=2 \\
10 \%\end{array}$ & $\begin{array}{c}f=15 \\
75 \%\end{array}$ & $\begin{array}{l}f=3 \\
15 \%\end{array}$ & Nil & 2.8 & 0.77 \\
\hline \multicolumn{9}{|l|}{ N. Exercises } \\
\hline 37 . They are adequate. & Nil & Nil & $\begin{array}{l}f=2 \\
10 \%\end{array}$ & $\begin{array}{c}f=16 \\
80 \%\end{array}$ & $\begin{array}{l}f=2 \\
10 \%\end{array}$ & Nil & 2.8 & 0.77 \\
\hline 38. They are interesting. & Nil & $\begin{array}{l}f=2 \\
10 \%\end{array}$ & $\begin{array}{l}f=6 \\
30 \%\end{array}$ & $\begin{array}{c}f=10 \\
50 \%\end{array}$ & $\begin{array}{l}f=3 \\
15 \%\end{array}$ & Nil & 2.95 & 0.83 \\
\hline 39. They help students with mixed abilities. & Nil & $\begin{array}{c}f=1 \\
5 \%\end{array}$ & $\begin{array}{l}f=4 \\
20 \%\end{array}$ & $\begin{array}{c}f=11 \\
55 \%\end{array}$ & $\begin{array}{l}f=4 \\
20 \%\end{array}$ & Nil & 2.85 & 0.88 \\
\hline
\end{tabular}


For checklist item 1, 80\% of the respondents gave score 3 (high usefulness) which shows the teachers felt that the textbook really matched the specification of the Year 6 English SK syllabus. A high mean score of 3.3, SD 0.47 , can be noticed for checklist item 3, and teachers felt that the activities in the book could be fully exploited. Based on Nimehchisalem \& Mukundan's (2015) interpretation guide (see Table 4.2, below), the findings show this current textbook is high in usefulness because the means for almost all the items are in the range of $2.81-3.60$ range.

Table 4.2 Checklist Interpretation Guide of Mean Scores (Nimehchisalem \& Mukundan, 2015)

\begin{tabular}{lll}
\hline Scores & Range & Interpretation \\
0 & $0.00-0.80$ & Negligible usefulness \\
1 & $0.81-1.60$ & Low usefulness \\
2 & $1.61-2.80$ & Moderate usefulness \\
3 & $2.81-3.60$ & High usefulness \\
5 & $3.61-4.00$ & Very high usefulness \\
\hline
\end{tabular}

The items with frequency scores in the range of $0-1$ have a mean range of $2.80-1.61$. This shows checklist items $10,11,12,14,15,16$, and 20 fell in this mean range and they were moderate in usefulness based on the percentage of score given by the teachers. Items 10, 11, and 12 are on efficient layout of supplementary materials of the textbook while items 14, 15, 16 are on general content, and item 20 is on listening skills. Item 10 in the checklist has the lowest mean of 1.65 but with a higher SD 1.09 because the scores ranked by the teachers were from 0 till 3 and they were tabulated far from the mean.

As a conclusion, based on the Tables 4.1 and 4.2 , the current textbook can be said to be compatible and suitable in terms of all items except for certain areas such as lacking information and exposure on supplementary and audio materials. The positive side of the findings is that the mean and SD scores for all the items are on high in usefulness, which clearly indicates that the new KSSR Year 6 SK textbook is a good choice made by the Ministry of Education. Table 4.3 shows the mean and SD scores for general attributes of the textbook.

Table 4.3 Mean and SD scores for General Attributes

\begin{tabular}{|l|c|c|}
\hline \multicolumn{1}{|c|}{ Components } & Mean & SD \\
\hline Syllabus and curriculum & 3.2 & 0.61 \\
\hline Methodology & 3.2 & 0.76 \\
\hline Suitability & 3.05 & 0.68 \\
\hline Physical and utilitarian attributes & 3.25 & 0.60 \\
\hline Efficient layout of supplementary materials & 1.83 & 1.01 \\
\hline
\end{tabular}

Overall $\mathrm{M}=\mathbf{2 . 8 2} \mathrm{SD}=\mathbf{0 . 9 6}$

Specifically, for components in general attributes in the current KSSR Year 6 textbook, the highest score $(\mathrm{M}=3.25, \mathrm{SD}=0.60)$ was found for the physical and utilitarian attributes, which comprises appropriate pricing, attractive layouts, and efficient use of texts and visuals. The book is 
priced at RM 9.90 and is considered to be a reasonable and affordable price, and the layout is said to be catchy and able attract the learners' interest.

Although syllabus and curriculum, and methodology have the same mean score $(M=3.2)$, the syllabus and curriculum subtheme have a better score as its SD is more scattered around its mean where else the methodology components have an SD of 0.76 , which means that the data are more dispersed. The respondents felt that the syllabus and curriculum are suitable for the current KSSR syllabus, and they gave a score of either 3 or 4 . The lowest mean score $(\mathrm{M}=1.83, \mathrm{SD} 1.01)$ was reported for efficient layout of supplementary materials. Teachers mostly were unsure about the supplementary materials provided for the current textbook. Looking at the findings on this item, many teachers gave scores between 0-2 only because they were not really guided or given any supplementary materials.

As a conclusion, general attributes do give a major impact on the selection of textbooks. The textbook evaluated positively with a good and high usefulness level for general attributes even though the supplementary materials show a low Mean and SD.

Table 4.4 Mean and SD scores for Learning-teaching Content

\begin{tabular}{|c|c|c|}
\hline Components & Mean & SD \\
\hline General Content & 2.77 & 0.74 \\
\hline Listening & 2.88 & 0.96 \\
\hline Speaking & 3.05 & 0.78 \\
\hline Reading & 3.10 & 0.57 \\
\hline Writing & 2.88 & 0.82 \\
\hline Vocabulary & 2.85 & 0.76 \\
\hline Grammar & 2.88 & 0.72 \\
\hline Pronunciation & 2.85 & 0.74 \\
\hline Exercises & 2.85 & 0.80 \\
\hline
\end{tabular}

Specifically, for components in learning-teaching content (see Table 4.4) in the current KSSR Year 6 textbook, the highest score $(\mathrm{M}=3.10, \mathrm{SD}=0.57)$ can be found for reading skills. Teachers gave a high score in this skill because they evaluated the texts provided in the textbook as sufficient for low to high levels and the difficulty level was appropriate too. Teachers felt that the length of text was appropriate, meaningful, and interesting.

Speaking skill has the second highest score $(\mathrm{M}=3.05, \mathrm{SD}=0.78)$ because teachers evaluated the book as having appropriate listening tasks which were developed to initiate meaningful communication, with well-defined goals. Besides, teachers agreed that there is individual, pair, and group speaking activities which have also been given equal emphasis. Three aspects in the learningteaching component scored the same mean with different SD and they are Listening $(\mathrm{M}=2.88, \mathrm{SD}=$ $0.96)$, Writing $(\mathrm{M}=2.88, \mathrm{SD}=0.82)$, and Grammar $(\mathrm{M}=2.88, \mathrm{SD}=0.72)$. 
From the above findings, listening skill has a better score in terms of SD compared to others. This means the scoring for listening is better compared to the other three skills. Teachers ranked it highest because they felt that the listening activities are appropriate and have well defined goals. Most of the tasks are authentic and close to real life situations. Apart from the listening skills, writing skills also has the same Mean but with slightly lower SD. Teachers felt that the writing tasks are varied and interesting. In addition, the learners' abilities have also been considered. Lastly the grammar aspect is said to be very contextualized and recurrent throughout the textbook.

The exercises, vocabulary and pronunciation elements also have the same Mean but with different $\mathrm{SD}$ for Exercises $(\mathrm{M}=2.85, \mathrm{SD}=0.80)$, Vocabulary $(\mathrm{M}=2.85, \mathrm{SD}=0.76)$, and Pronunciation $(\mathrm{M}=2.85, \mathrm{SD}=0.74)$. The $\mathrm{SD}$ value for the exercises criteria is higher because teachers consider the instructions to be clear for each exercise, adequate, interesting, and able to help students with different abilities. Next, the teachers deem the vocabulary in terms of word load in each unit as equally introduced with a good distribution throughout the entire textbook. The words are contextualized and taught based on students' levels and abilities. The general content reported the lowest mean value $(\mathrm{M}=2.77, \mathrm{SD}=0.74)$.

\subsection{Teachers Perceptions about the Suitability of the KSSR Year 6 Textbook (Qualitative Data)}

The interviews were carried out involving five teachers who are teaching Year 6 students. This interview was conducted to find out the perceptions of the teachers towards the suitability of the Year 6 KSSR (SK) English Textbook to the learners. Their responses gave valuable insight towards the betterment of the current textbook especially in tackling the study needs in the future. The themes used to interpret the interview were sufficiency, suitability to learners, learning-teaching content, and English language skills (listening, speaking, reading, and writing). Based on the interviews, in general all of them said they are satisfied with the textbook as it is suitable for both the learners and teachers. Teachers agreed that the current textbook was sufficient and could be the main reference for the learners and suitable for their age in terms of content, illustrations, and needs of learners. Looking at the theme related to learning-teaching content, all five teachers agreed that all four main skills were covered equally and were arranged accordingly from listening and speaking, reading, and writing skills throughout the textbook. When looking at each skill specifically, some teachers suggested to have audio as supplementary materials for the listening skills to give more exposure to this skill. Some teachers also commented that speaking activities in the book were interesting and many new issues were discussed. For the reading skills, the teachers felt that the content was sufficient but need to have more variety types of reading texts such as news, brochures, and dialogues. Lastly the writing skills tasks and exposure to writing are said to be suitable for all three levels of learners but suggested that additional UPSR writing format should be added.

In summary, looking at both the quantitative and qualitative findings, it can be said that the Year 6 KSSR English SK Textbook presently used in Johor primary SK schools is highly useful for the learners, in terms of general attributes and learning-teaching content. The findings from the checklist showed that the current textbook was high in usefulness in terms of its general attributes in relation to syllabus and curriculum, the methodology, the book's suitability to learners, and physical and utilitarian attributes. Unfortunately, one aspect of efficient outlay of supplementary materials 
was moderate in usefulness because the current textbook as many schools and teachers were unaware of the supporting materials provided. Secondly, from the aspect of learning-teaching content, the findings also showed high usefulness. The eight important aspects covered were speaking, grammar, listening, reading, and writing skills, vocabulary, pronunciation, and exercises.

\subsection{CONCLUSION}

This study investigated the suitability of the current Year 6 KSSR (SK) English textbook towards the learners from the perception of teachers. It has expanded upon research on textbook evaluation and provides some insights on the effectiveness and suitability of the Year 6 KSSR (SK) English textbook to teachers and textbook designers. The textbook was published in the year of 2015 by local authors. The findings from the mixed-mode design showed that the textbook used in primary schools, is highly beneficial for the pupils in terms of general attributes and learning-teaching content of the textbook. In recent years, more countries including Malaysia have adopted the CEFR for English Language. This move has brought in globally produced textbooks and textbooks such as the Year 6 KSSR English textbook are being phased out and replaced with globally produced textbooks. Evaluation of the new 'global' textbooks such as Pulse 2, Get Smart and Super Minds have raised concerns about the limitations of the textbooks. Studies based on teachers' perceptions show that the new 'global' textbooks also need improvements to meet local learner needs, among others, in terms of cultural content as the new textbooks are based on international cultures. This has led to more challenges for teachers when using these textbooks. To overcome this concern, we suggest that the 'global' textbooks be adapted to suit local needs. Thus, rather than adopting the books, these books could be 'customised' to suit local learner needs. In this way, creating a custom textbook could be done by bringing in Malaysian authors and textbook designers who have vast experience and knowledge in ELT textbook design. A customized Pulse 2 or get Smart, for example, would then be infused with local culture and improved based on the perceptions of teachers, which would be better suited than the global textbooks in their original form that are meant for an international context. Perceptions of teachers, as the end users of the textbooks, should be given more importance when selecting textbooks. In fact, textbook evaluation should be a crucial part of textbook selection. Most selections are undertaken by the Ministry of Education (MOE) with its team of experts that may include experienced teachers. We suggest textbook evaluation by the teachers who are themselves using the textbooks, as a key step for the selection of textbooks. Thus, this calls for evaluation of textbooks prior to selection and use, as well as while-in-use, as this could help the Ministry of Education (MOE) to reconsider the suitability of the textbooks that have been prescribed for use in Malaysian schools. 


\section{REFERENCES}

Abdul Rahim, H., \& Jalalian Daghigh, A. 2019. Locally Developed Versus Global Textbooks: An Evaluation of Cultural Content in Textbooks Used in English Language Teaching in Malaysia. Asian Englishes. 1-15. Doi:10.1080/13488678.2019.1669301

Brown, D. H. 2000. Principles of Language Learning \& Teaching. 4th ed. New York: Longman. 49-58. Byrd, P. 2001. Textbooks: Evaluation for Selection And Analysis for Implementation. In M. CelceMurcia (ed.). Teaching English a Second of Foreign Language. 3rd ed. Boston: Heinle \& Heinle/ Thompson Learning. 415-424.

Cunningsworth, A. 1984. Evaluating and Selecting EFL Teaching Materials. London: Heinemann. Cunningsworth, A. 1995. Choosing Your Coursebook. Oxford: Macmillan Education.

Johar, N. A. \& Abdul Aziz, A. 2019. Teachers' Perceptions on using the Pulse 2 Textbook. Journal of Educational Research and Indigenous Studies. 2(1): 2-16.

Khoo, H. S. 2015. Teachers' Evaluation of KBSM Form 4, 5 English Textbooks Used in the Secondary Schools in Penang, Malaysia. Advances in Language and Literary Studies. 128-131.

Kurkgöz, Y. 2009. Evaluating the English Textbooks for Young Learners of English at Turkish Primary Education. Procedia Social and Behavioral Sciences.

McGrath, I. 2002. Materials Evaluation and Design for Language Teaching. Edinburgh: Edinburgh University Press.

Mohammad Din, F. F. \& Yamat, H. 2020. Challenges faced by teachers in using Supermind Textbook. International Journal of Academic Research in Progressive Education and Development. 9(1): 122-133.

Mohamad Uri, N. F. and Abd Aziz, M. S. 2018. Implementation of CEFR in Malaysia: Teachers ${ }^{\text {ee }}$ Awareness and the Challenges. 3L: The Southeast Asian Journal of English Language Studies 24(3): 168-183.

Mukundan, J., Hajimohammadi, R., \&Nimehchisalem, V. 2011. Developing an English Language Textbook Evaluation Checklist. Contemporary Issues in Education Research. 4(6): 21-27

M Mukundan, J., \& Kalajahi, S. A. R. 2013. Evaluation of Malaysian English Language Teaching Textbooks. International Journal of Education and Literacy Studies. 1(1): 38-46.

Mukundan, V. N. 2015. Refinement of the English Language Teaching Textbook Evaluation Checklist. Pertanika Journal of Social Science and Humanities. 761-780.

Neill, R. O. 1982. Why Use Textbook? ELT Journal. 36/2: 104-111.

Renandya, J. C. 2002. Methodology in Language Teaching. Edinburgh, UK: Cambridge University Press.

Richards, J. C. 2001. Curriculum Development in Language Education. Cambridge University Press.

Sheldon, L. 1988. Evaluating ELT Textbooks and Materials. ELT Journal. 42(4): 237-246.

Sungif, N. A. 2014. Evaluation of Malaysian Primary English Language Textbooks. Advances in Language and Literary Studies. 5: 5-9.

Tomlinson, B. 1998. Materials Development. UK: Cambridge University Press.

Tomlinson, B. 2008. English Language Learning Material. NY: Continnum Publishing Group.

Hutchinson, T. \& Torres, E. 1994. The Textbook as Agent Of Change. ELT Journal. 48/4: 315-328. 
Ur, P. 1996. A Course in English Language Teaching. UK: Cambridge Unversity Press.

Williams, D. 1983. Developing criteria for textbook evaluation. ELTJournal. 37/3: 251-255.

Yuasa, K. 2010. English Textbooks in Japan and Korea. Pan-Pacific Association of Applied Linguistic, 14/1: 147-158. 